\section{Oleksyshen V., Sokolskyi A., Kolosov A., Solovei V.}

\title{
DETERMINATION OF GEOMETRIC AND KINEMATIC CHARACTERISTICS OF FDM 3D PRINT PROCESS
}

Досліджено процес нанесення полімерного термопластичного матеріалу в процесі 3 D друку з використанням технологіï FDM (Fused Deposition Modeling - формування методом наплавки). Об'єктом дослідження став дискретний шар дослідного зразка. Для визначення геометричних параметрів було виготовлено зразки товщиною в один діаметр сопла (0,5 мм) друкувальної головки $3 D$ принтера. Отримані зразки розрізані на ділянки однакової ширини (10 мм), на кожній ділянці було відсічено окремій шар нанесеного матеріалу. Це дало змогу визначити зміну товщини від початкової до кінцевої точки шару. Виявилось, що товщина шару менша за діаметр сопла на початку руху друкувальної головки поступово зростає та на певному етапі починає перевищувати діаметр сопла. Отримані значення становили від 0,4 до 0,6 мм для сопла діаметром 0,5 мм. Причина полягає в тому, що на початку подачі витратного матеріалу має місце високоеластичне запізнення реакиї полімерного матеріалу на тиск у друкувальній головиі та певний проміжок часу ия частина матеріалу не наноситься на зразок, а потім має місие ефект розбухання розплаву полімеру. Причому зі зростанням діаметра сопла вплив цих явиш, також зростає. Також прочес друку фіксувався на широкоформатну відеокамеру у НD-якості з частотою 50 кадрів/c, що дало змогу дослідити динаміку нанесення витратного полімерного термопластичного матеріалу. Отримані результати показали відмінність швидкостей від заданих у виконавчому коді. При чому для різних конструкцій кінематичних схем переміщення друкувальної головки відхилення параметрів було різним - реальні значення були більшими від теоретичних (заданих) на 20-50\% в залежності від типу FDM 3D принтера. Це пояснюється відмінністю інериійних характеристик різних конструкцій кінематичних схем переміщення друкувальної головки. Отримані результати є основою для подальшого більш детального вивчення впливу конфігурацї формуючих органів та конструкиї FDM 3 D принтерів на процес просторового друку.

ключові слова: $3 D$ друк, 3D принтер, Fused Deposition Modeling, полімерний термопластичний матеріал, друкувальна головка, кінематична схема.

Received date: 31.01 .2020

Accepted date: 02.03 .2020

Published date: 30.04 .2020
Copyright (C) 2020, Oleksyshen V., Sokolskyi A., Kolosov A., Solovei V. This is an open access article under the CC BY license (http://creativecommons.org/licenses/by/4.0)

\section{Introduction}

The technology of additive production in recent years has become widespread in almost all spheres of human life and industries. Every second manufacturer in the world is increasing investments in additive manufacturing. Already more than $80 \%$ of prototypes and $60 \%$ of functional units are manufactured using 3D printing [1]. Analysts around the world see explosive growth in additive manufacturing technology. Equipment manufacturers usually invest the main resources in the development of new models and types of equipment. However, the process of product formation itself remains poorly understood. The instability of the $3 \mathrm{D}$ printing process is often observed, it is difficult to foresee at the stage of product modeling. The operators of this equipment often deal with various defects resulting from 3D printing. The causes and nature, and most importantly, the prediction of the appearance of such defects are unknown.

The basic principle of additive manufacturing is the layering of structural material according to the digital model of the product. The most common additive technology is FDM (Fused Deposition Modeling) [2]. The devices of this technology use a polymer consumable in the form of a rod of a stable diameter - filament. When forming the product, the molten material is applied to an already frozen layer. It is known that polymeric materials have characteristics that are interchangeable with temperature and strain rate. It is this feature that creates problems when printing with one or another consumable polymeric material. The main place for the appearance of defects is the line between the cold and hot layer. Therefore, it is of interest to study the properties between the layers of the material. To study this issue, tests of printed samples for strength were carried out.

Similar studies were conducted by scientists from the University of Florida and the College of Engineering at the University of California at Berkeley [3]. The researchers tested a number of samples for tensile and shear forces made of ABS and PC. One of the main conclusions is the anisotropy of the mechanical properties between stretching along and across the layers of the material (about $30 \%$ ). However, research does not allow to establish the strength of interlayer adhesion and geometric characteristics in the contact zone of the layers.

Similar studies were also carried out [4-6], in which various materials were tested with different printing parameters. The main disadvantages are that in all studies, 
the conditions for the manufacture of samples were very variable. Comparing the results for the same materials, a difference in values should be noted. This can be explained by the anisotropy of properties and the heterogeneity of the structure of printed samples.

Of particular interest is the study [7]. This study shows a macro photo of the cross section of the structure of samples printed by nozzles of various diameters and with different layer thicknesses. They show that the internal volume includes a large number of cavities, and their shape and size are unstable.

The structure of printed products is generally poorly defined, so the physical characteristics of the samples are also ambiguous. Therefore, it is necessary to study the process of applying the material along the layer, to determine the geometric parameters of a single layer.

So, the object of research is the geometric parameters of the discrete layer of the prototype. The aim of research is to establish patterns of influence such as kinematics and operating modes of $3 \mathrm{D}$ printers on the uniformity and speed of spatial printing.

\section{Methods of research}

Based on the previous studies performed by the authors, uneven results were revealed for each type of sample. In addition, in each group of strength tests there were a certain number of experiments that fall out of the general picture. Therefore, it is necessary to study in detail the geometric parameters and dynamics of the process of applying the material within a single layer.

The $t_{d}=$ determination of the geometric parameters of an individual layer was carried out according to the following procedure:

1. 10 rectangular samples are produced (Fig. 1) with a length of $100 \mathrm{~mm}$, a height of $20 \mathrm{~mm}$ and a thickness equal to the diameter of the nozzle $0.5 \mathrm{~mm}$.

2. The print parameters are as follows: printing speed $V_{p}=30 \mathrm{~mm} / \mathrm{s}$; printing temperature $V_{p}=220^{\circ} \mathrm{C}$; layer thickness $h_{l}=0.2 \mathrm{~mm}$. The resulting samples were cut every $10 \mathrm{~mm}$. For the obtained segments, the thickness and mass were measured.

As a recyclable material, polylactide (PLA) was used.

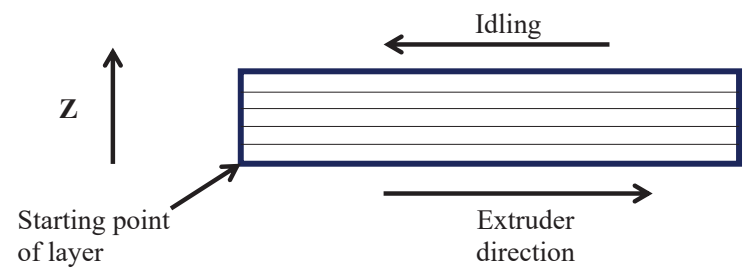

Fig. 1. Scheme for printing samples

The determination of the dynamics of the layer was carried out according to the following method:

1. The samples were modeled $100 \mathrm{~mm}$ long and $20 \mathrm{~mm}$ high with a scale in the form of walls every $10 \mathrm{~mm}$ (Fig. 2). The thickness of the samples is equal to the diameter of the nozzle.

2. Printing parameters met the most optimal conditions in accordance with previous studies: $t_{p}=220^{\circ} \mathrm{C} ; V_{p}=30 \mathrm{~mm} / \mathrm{s}$. The transition to the next layer occurred at one point, so the material is applied when moving the extruder from left to right, in the opposite direction, the idle stroke.

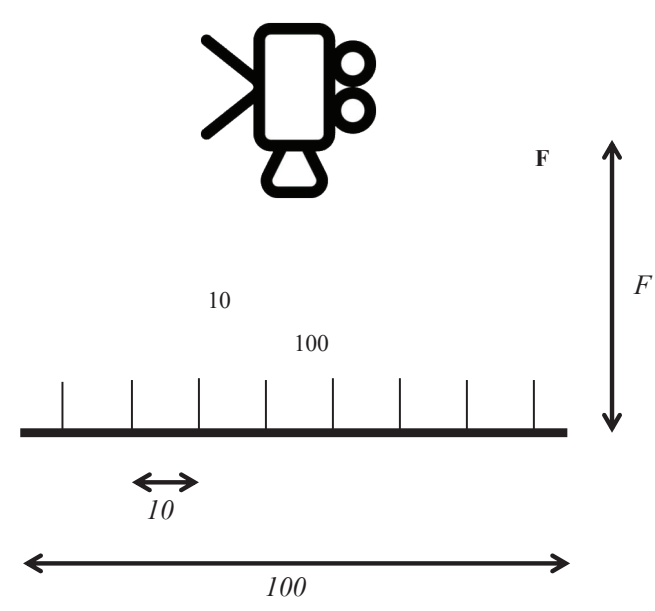

Fig. 2. The process of shooting the $3 D$ printing process

3. The sample was placed along the $X$ axis of the $3 \mathrm{D}$ printer. On the contrary, a video camera is installed at the level of the working platform, focuses on the sample.

4. After completion of the scale, the camera turns on and the process of printing several layers is removed. For one sample, the survey is repeated 2-3 times.

5. These operations must be done for printers with mechanics such as Prusa i3 and H-Bot.

6 . For the captured videos, frames are selected that correspond to the process of building one layer from the beginning of the application of the material to the return of the extruder to the zero position by reverse idle.

7. Each passage is reviewed frame by frame and the number of frames for each section is considered to be $10 \mathrm{~mm}$. The number of frames per stop at the zero point of the layer is considered.

\section{Research results and discussion}

The results of measurements of the geometric parameters of the layer are as follows (Fig. 3, 4).

Based on the results, it is found that the thickness of the layer is uneven. At the beginning of the layer, the thickness is less than the diameter of the nozzle, gradually increasing and toward the end of the layer becomes larger than the diameter of the nozzle. Also, in the interval from the beginning of the layer to the middle, delamination Is present. That is, at the beginning of the movement there is an underextrusion, and at the end a «swelling» of the layer (Fig. 4, 5).

The distribution of the print head movement speeds within the framework of the formation of one layer for two types of $3 \mathrm{D}$ printers: Prusa i3 [8] and H-Bot [9] is established. The results are shown in Fig. 5, 6.

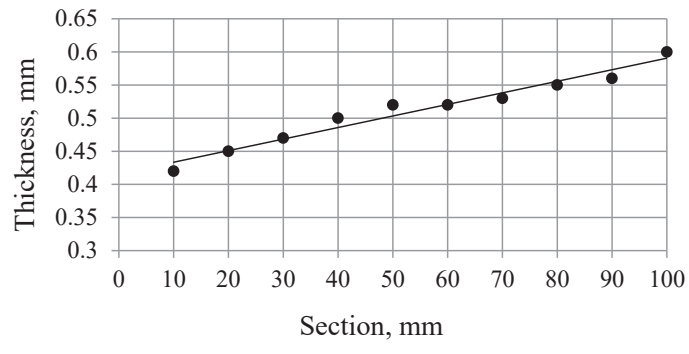

Fig. 3. Changing the thickness of the extruded PLA layer from the print start point 


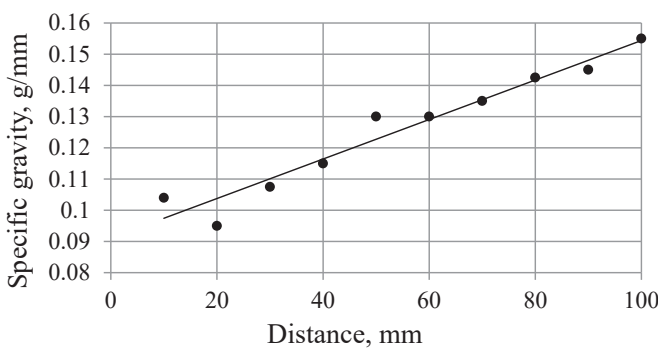

Fig. 4. Changing the thickness of the extruded PLA layer from the print start point

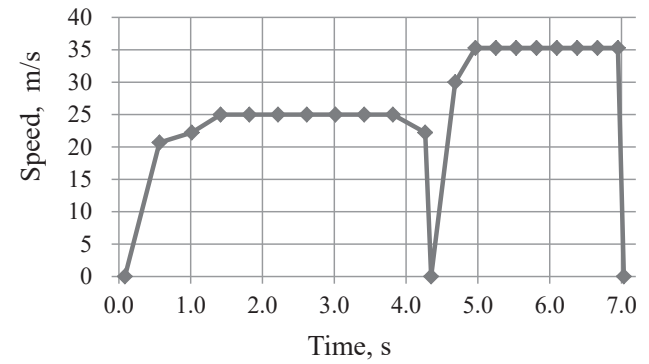

Fig. 5. Graph of the $3 D$ printer extruder speed with Prusa i3 mechanics

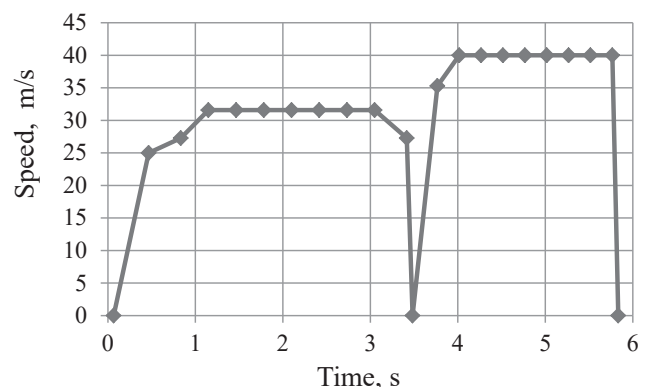

Fig. 6. Graph of the 3D printer extruder speed with H-Bot mechanics

The obtained results show the dynamics of the extruder along the layer. Data from the speeds shows a difference from the settings in Cura Slicers [10]. For both types of mechanics, it turned out that the actual average speed is less than the specified one. Moreover, for each type of mechanics this difference is different.

To determine the difference, let's determine the difference in the printing time of the samples from theoretical at different printing speeds for various designs of 3D printers (Fig. 7).

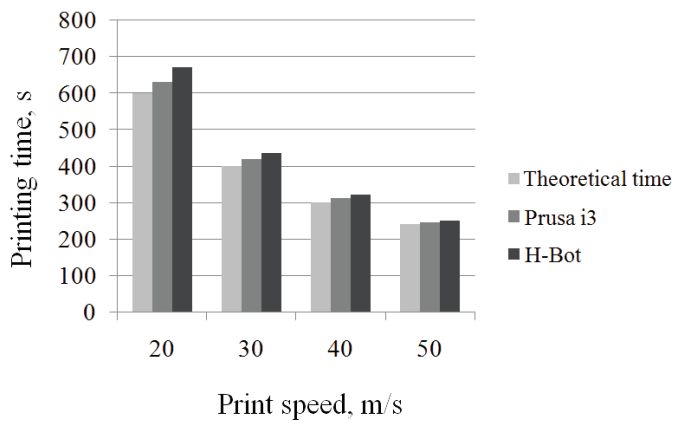

Fig. 7. Printing time for samples on different printers at different speeds

As can be seen from Fig. 7, with increasing printing speed, the difference from the theoretical printing time from the actual one gradually decreases. Moreover, prints for $\mathrm{H}$-Bot mechanics are always more than printing on Prusa i3.

\section{Conclusions}

The results of experimental studies of 3D printing show that each polymer layer is applied unevenly, increasing in length. Actual printing is always more theoretical, the time difference gradually increases with decreasing printing speed. Printers with H-Bot kinematics show a greater deviation from the theoretical printing speed than printers with Prusa kinematics. The results are the basis for further more detailed study of the influence of the configuration of the forming organs and the design of FDM 3D printers on the spatial printing process.

\section{References}

1. Wohlers Report 2013. Available at: https://wohlersassociates. com/press59.html

2. Surange, V. G., Gharat, P. V. (2016). 3D Printing Process Using Fused Deposition Modelling (FDM). International Research Journal of Engineering and Technology (IRJET), 3 (3). Available at: https://www.researchgate.net/publication/301557905_3D Printing_Process_Using_Fused_Deposition_Modelling_FDM

3. Cantrell, J. T., Rohde, S., Damiani, D., Gurnani, R., DiSandro, L Anton, J. et. al. (2017). Experimental characterization of the mechanical properties of 3D-printed ABS and polycarbonate parts. Rapid Prototyping Journal, 23 (4), 811-824. doi: http:// doi.org/10.1108/rpj-03-2016-0042

4. Divyathej, M., Varun, M., Rajeev, P. (2016). Analysis of mechanical behavior of 3D printed ABS parts by experiments. International Journal of Scientific \& Engineering Research, 7 (3). Available at: https://www.ijser.org/researchpaper/Analysis-of-mechanicalbehavior-of-3D-printed-ABS-parts-by-experiments.pdf

5. Letcher, T., Waytashek, M. (2014). Material Property Testing of 3D-Printed Specimen in PLA on an Entry-Level 3D Printer. Volume 2A: Advanced Manufacturing. doi: http://doi.org/ 10.1115/imece2014-39379

6. Johnson, G. A., French, J. J. (2018). Evaluation of Infill Effect on Mechanical Properties of Consumer 3D Printing Materials. Advances in Technology Innovation, 3 (4), 179-184.

7. Kuznetsov, V., Solonin, A., Urzhumtsev, O., Schilling, R., Tavitov, A. (2018). Strength of PLA Components Fabricated with Fused Deposition Technology Using a Desktop 3D Printer as a Function of Geometrical Parameters of the Process. Polymers, 10 (3), 313. doi: http://doi.org/10.3390/polym10030313

8. Prusa resurch. Available at: https://www.prusa3d.com/

9. Weikert, S., Ratnaweera, R., Zirn, O. (2010). Modeling and measurement of H-Bot kinematic systems. Swiss Federal Institute of Technology. Zurich. Available at: https:/ www.icvr.ethz.ch/ConfiguratorJM/publications/MODELING_A_132687166151936/3314_ mod.pdf

10. Ultimaker Cura. Available at: https://ultimaker.com/en/ resources/52833-install-ultimaker-cura

Oleksyshen Vitalii, Postgraduate Student, Department of Chemical, Polymeric and Silicate Engineering, National Technical University of Ukraine «Igor Sikorsky Kyiv Polytechnic Institute», Ukraine, e-mail: vitaliy.oleksishen@gmail.com, ORCID: https://orcid.org/00000002-0477-2388

Sokolskyi Aleksandr, PhD, Associate Professor, Department of Chemical, Polymeric and Silicate Machine Building, National Technical University of Ukraine «Igor Sikorsky Kyiv Polytechnic Institute»,Ukraine, e-mail: sokolkiev@ukr.net, ORCID: http://orcid.org/ 0000-0002-7929-3576

Kolosov Oleksandr, Doctor of Technical Sciences, Professor, Senior Researcher, Member of Academy of Sciences of Higher Education of Ukraine, Ukrainian Patent Attorney, Department of Chemical, Polymeric and Silicate Machine Building, National Technical University of Ukraine «Igor Sikorsky Kyiv Polytechnic Institute», Ukraine, e-mail: a-kolosov@ukr.net, ORCID: http://orcid.org/0000-0001-8939-0591

Solovei Vladyslav, Postgraduate Student, Department of Chemical, Polymeric and Silicate Engineering, National Technical University of Ukraine «Igor Sikorsky Kyiv Polytechnic Institute», Ukraine, e-mail: vl_solovej84@gmail.com, ORCID: http://orcid.org/00000002-5638-2701 